\begin{tabular}{l|l|l}
\hline \hline Vol. 27(2):231-235 & Ocean and Polar Research & June 2005 \\
\hline \hline
\end{tabular}

\title{
Note
}

\section{Ecological and Biogeochemical Response of Antarctic Ecosystems to Iron Fertilization and Implications on Global Carbon Cycle}

\author{
Ulrich Bathmann* \\ Alfred Wegener Institute for Polar and Marine Research (AWI) \\ D-27515 Bremerhaven, Germany
}

\begin{abstract}
The European Iron Fertilization Experiment EIFEX studied the growth and decline of a phytoplankton bloom stimulated by fertilising $10 \mathrm{~km}^{2}$ in the core of a mesoscale $(80 \times 120 \mathrm{~km})$ cyclonic eddy south of the Antarctic Polar Front with about 2 times 7 tonnes of iron sulphate. The phytoplankton accumulation induced by iron fertilization did not exceed $3 \mu \mathrm{g} \mathrm{chl} \mathrm{a} l^{-1}$ despite a draw down of $5 \mu \mathrm{M}$ of nitrate that should have resulted in at least double to triple the amount of phytoplankton biomass assuming regular Redfield-ratios for draw down after phytoplankton growth in the Southern Ocean. During EIFEX the fertilized core of the mesoscale eddy evolved to a hotspot for a variety of small and medium sized mesozooplankton copepods. In contrast to copepods, the biomass of salps (Salpa thompsoni) that dominated zooplankton biomass before the onset of our experiment decreased to nearly extinction. Most of the species of the mesozooplankton community showed extremely high feeding rates compared to literature values from Southern Ocean summer communities. At the end of the experiment, massive phytoplankton sedimentation reached the sea floor at about $3800 \mathrm{~m}$ water depth.
\end{abstract}

Key words : Antarctic ecosystem, iron fertilization, carbon cycle, mesozooplankton

\section{Introduction}

The European Iron Fertilization Experiment (EIFEX, Fig. 1) studied the growth and decline of a phytoplankton bloom stimulated by fertilising $10 \mathrm{~km}^{2}$ in the core of a mesoscale $(80 \times 120 \mathrm{~km})$ cyclonic eddy (Strass et al. 2005) south of the Antarctic Polar Front (Fig. 2) with about 2 times 7 tonnes of iron sulphate. Iron was shown to be the limiting factor of phytoplankton growth by seven previous experiments (Boyd et al. 2000; Landry et al. 2000; Coale et al. 2003; Martin and Fitzwater 1988; Abraham et al. 2000; Buesseler et al. 2005; Coale et al. 1996; Coale et al. 2004; Smetacek 2001) in so called high nutrient - low chlorophyll (HNLC) regions of the world oceans. All of those experiments -2 in the Equatorial Pacific (Ironex I and II), 3 in the Southern Ocean (SOIREE, EISENEX, SOFEX), and 2 in the Subarctic Pacific lasted only a few weeks leaving insufficient time to determine the fate of the iron induced, newly formed

\footnotetext{
*Author. E-mail : ubathmann@awi-bremerhaven.de
}

phytoplankton biomass.

The overarching goal of EIFEX was to further our understanding how open ocean ecosystem function in the

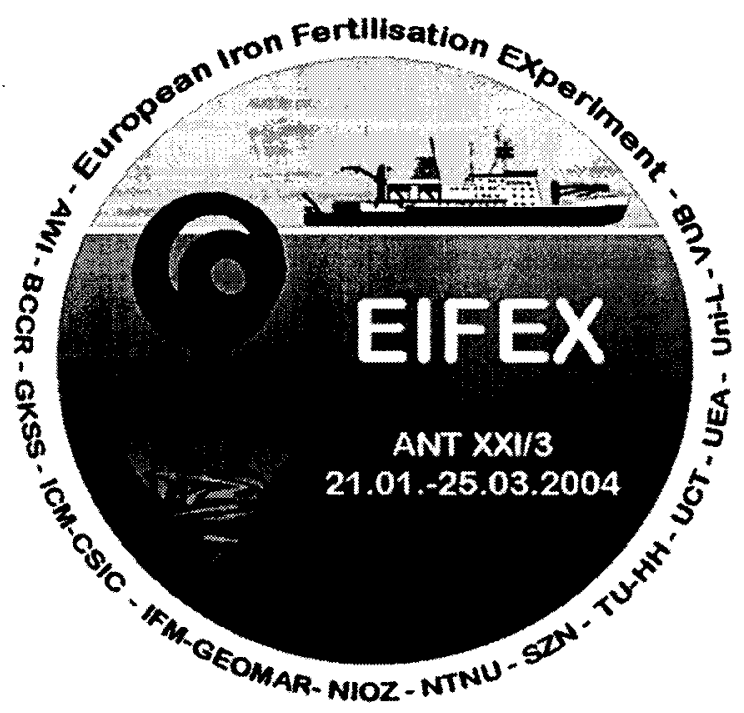

Fig. 1. Cruise Logo (courtesy by Maike Schmidt). 


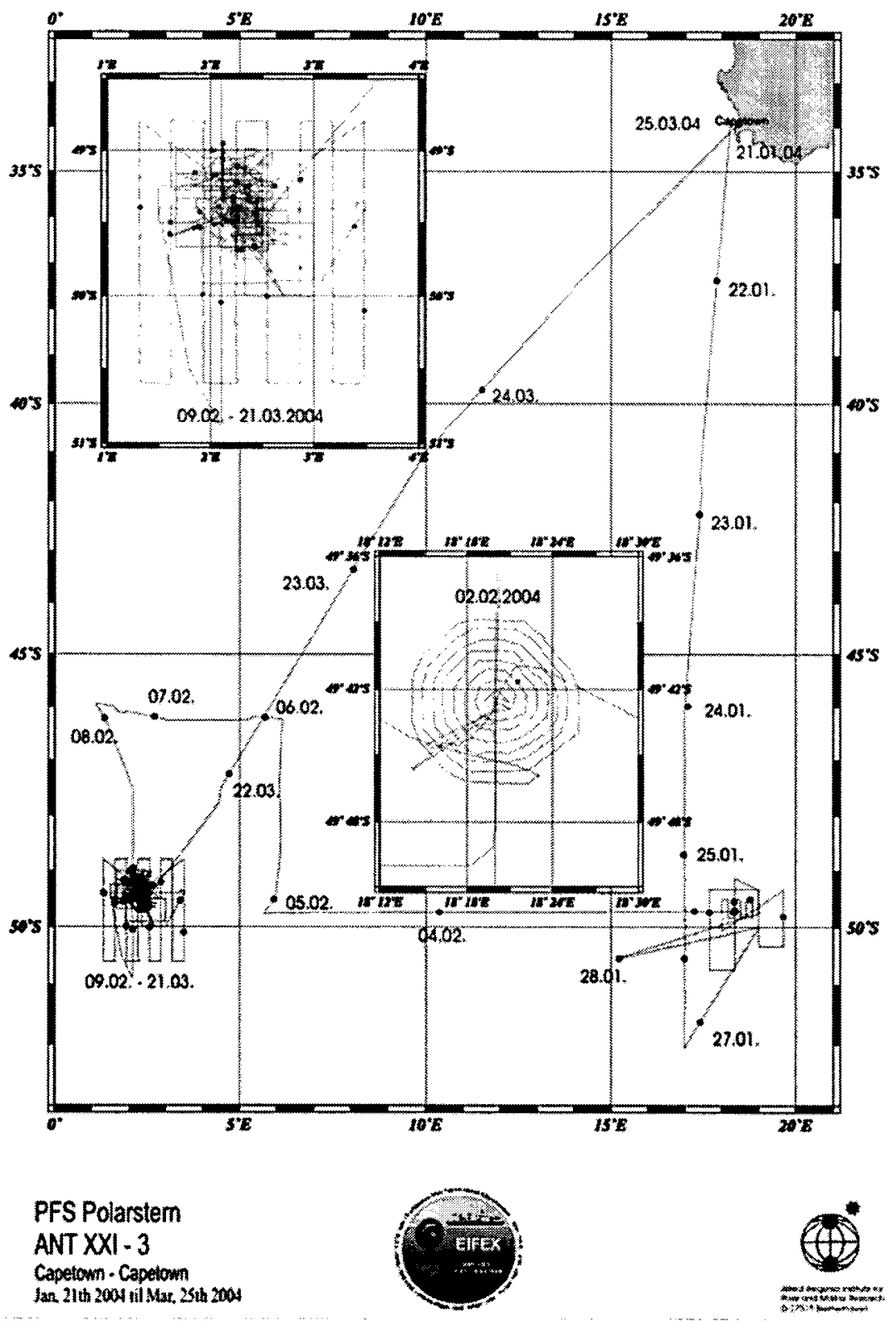

Fig. 2. Cruise track with inserts (courtesy by FIELAX).

course of glacial-interglacial cycles, and how the species of the plankton communities interact with one another and with the environment, and how these species drive biogeochemical cycles. During glacial periods the atmosphere was loaded with dust particles containing iron from land soils to a much higher degree compared to interglacial cycles (Mahowald et al. 1999). As indicated by sediment cores (Bramati et al. 1997) and ice core (Delmonte et al. 2002), this iron dust was transported into remote areas of the glacial ocean that are known today as HNLC areas and that see very little input of iron from the atmosphere today. Another source of biological available iron in ocean surface waters originates from melting ice bergs (Strass et al. 2002), e.g. that are transported from high latitude waters to the Polar Front. This process is best known in so-called ice berg years in the Antarctic Circumpolar Current (ACC) at the location of the Antarctic Polar Front (APF). Thus, the artificial iron fertilization carried out 
during EIFEX simulates natural processes that introduce iron to iron-limited, land-remote ocean waters.

The structure and succession of a pelagic food web after artificial iron fertilization depends on growth rates by the various phytoplankton species and the subsequent accumulation of plankton biomass. The latter is the net product of production and loss due to grazing by pelagic heterotrophs (bacteria, protozoo- and metazooplankton) and otherwise induced mortality (e.g. viruses). All of these biological processes in turn are influenced by a range of physical (e.g. vertical mixing, light penetration depth) and chemical (e.g. concentration of iron and other trace elements, ratio of silicate to nitrate) factors that together determine the environment for living and growth. Most likely those effects are species specific and moreover might be different in different pelagic food webs as will be discussed below.

\section{The experiment}

EIFEX lasted for continuous 9 weeks with adequately interdisciplinary sampling of physical, chemical, biochemical, and biological parameters by the 55 scientists aboard RV POLARSTERN. (Smetacek et al. 2005). During a consecutive cruise the study site was sampled again 11 weeks after the start of the experiment.

\section{Results and discussion}

A main focus of EIFEX was to study the relationship between growth of phytoplankton and the concomitant effect of grazing on phytoplankton species composition and biomass, and to determine the breakdown of the inventories of biogenic elements in the surface layers of the ACC. The phytoplankton accumulation induced by iron fertilization did not exceed $3 \mu \mathrm{g} \mathrm{chl} \mathrm{a} l^{-1}$ (Klaas et al. in preparation) despite a draw down of $5 \mu \mathrm{M}$ of nitrate that should have resulted in at least double to triple the amount of phytoplankton biomass assuming regular Redfield-ratios for draw down after phytoplankton growth in the Southern Ocean (C:N $=9$ to 11; Riebesell et al. in preparation; $\mathrm{C}$ : $\mathrm{chl} \mathrm{a}=30$ to 80 ). We assume that sinking (sedimentation) of phytoplankton cells and grazing by proto- and mesozooplankton accounted for the additional loss. In the following both processes will be explained in more detail.

Small (cyclopoid) copepods became known to be efficient grazer in the Southern Ocean (Dubischar et al. 2002). During EIFEX the fertilized core of the mesoscale eddy evolved to a hotspot for a variety of small and medium sized mesozooplankton copepods (Krägefsky et al. in preparation). In contrast to copepods, the biomass of salps (Salpa thompsoni) that dominated zooplankton biomass before the onset of our experiment decreased to nearly extinction (von Harbou et al. in preparation). Most of the species of the mesozooplankton community showed extremely high feeding rates compared to literature values from Southern Ocean summer communities (Bathmann et $a l$. in preparation). We explain these shifts in species composition as zooplankton response to increased phytoplankton biomass production and the concurrent change in species composition, in the non-silicified, flagellate dominated phytoplankton assemblage of the microbial food web as well as within the slower growing diatom fraction (Assmy et al. in preparation). Protozooplankter remained rather constant on biomass levels but also showed high growth rates (turnover rates) (Henjes et al. in preparation) indicating that protozooplankter did efficiently top-down control the microbial food web but also were kept under control by mesozooplankton (copepod) grazing (Smetacek et al. 2004). At the end of the experiment, massive phytoplankton sedimentation reached the sea floor at about $3800 \mathrm{~m}$ water depth. This was recorded in CTD profiles down to the sea floor (Strass et al. in prep), by microscopically derived records of phytoplankton cells sinking (Assmy et al. in prep.), by pigment analysis of organic fluff accumulating on the deep-sea floor (Peeken et al. in prep) and by in situ oxygen profiles that were taken 11 weeks after the start of the experiment in the first few centimetres of the sediments underlying the study site (Sachs et al. in prep). Such a direct impact of fresh plankton material was the first ever recorded in deep-sea Antarctic waters.

\section{Conclusion}

From the experiment we conclude that iron fertilisation in the Southern Ocean may stimulate new carbon production but only in areas where hydrographical conditions stabilise the upper water layers for at least two to three weeks. Depending on phytoplankton species composition at the onset of the experiment, the physico-chemical conditions of the upper mixed water layer and the grazing pressure, the fate of the newly fixed carbon might be quite different. We postulate that similar conditions of iron fertilization compared to EIFEX but at larger scale may occur naturally today (e.g. during melting of ice bergs being transported into the Antarctic Polar frontal Zone) or may have occurred during the last glacial maximum when 
stronger winds may have transported more dust (with iron) from arid areas on land to high ocean areas (Mahowald et al. 1999). Thus, the physical-chemical-biological mechanisms and processes detected during EIFEX will enhance our understanding how the global carbon cycle is regulated.

\section{Acknowledgements}

This note is a contribution from the ship-board party as a team, and details are found in our expedition report (Smetacek et al., 2005).

\section{References}

Abraham, E.R., C.S. Law, P.W. Boyd, S.J. Lavender, M.T. Maldonado, and A.R. Bowie. 2000. Importance of stirring in the development of an iron-fertilized phytoplankton bloom. Nature, 407, 727-730.

Assmy, P., J. Henjes, M. Montresor, and V. Smetacek. Response and patterns of diatom species dominance: first results. (in preparation)

Bathmann, U., S. Jansen, S. Krägefsky, and L. von Harbou. Zooplankton response to iron fertilization in the Southem Ocean during EIFEX. (in preparation)

Boyd, P.W., A.J. Watson, C.S. Law, E.R. Abraham, T. Trull, R. Murdoch, D.C.E. Bakker, A.R. Bowie, K.O. Buesseler, H. Chang, M. Charette, P. Croot, K. Downing, R. Frew, M. Gall, M. Hatfield, J. Hall, M. Harvey, G. Jameson, J. LaRoche, M. Liddicoat, R. Ling, M.T. Maldonado, R.M. McKay, S. Noddler, S. Pickmere, R. Pridmore, S. Rintoul, K. Safi, P. Sutton, R. Strzepek, K. Tanneberger, S. Turner, A. Waite, and J. Zeldis. 2000. A mesoscale phytoplankton bloom in the polar Southern Ocean stimulated by iron fertilization. Nature, 407, 695702.

Brambati, A., G.P. Fanzutti, F. Finocchiaro, R. Melis, M. Frignani, M. Ravailoli, and M. Setti. 1997. Paleoenvironmental record in core Anta 91-30 (Drygalski Basin, Ross Sea, Antarctica). Antarct. Res. Ser., 72, 137-151.

Buesseler, K.O., J.E. Andrews, S.M. Pike, M.A. Charette, L.E. Goldson, M.A. Brzezinski, and V.P. Lance. 2005. Particle export during the Southem Ocean Iron Experiment (SOFeX). Limnol. Oceanogr., 50, 311-327.

Coale, K.H. et al. 2004. Southem Ocean Iron Enrichment Experiment: Carbon Cycling in High- and Low-Si Waters. Science, 304, 408-414.

Coale, K.H., K.S. Johnson, S.E. Fitzwater, R.M. Gordon, S. Tanner, F. Millero, P. Steinberg, P. Nightingale, D. Cooper, W.P. Cochlan, M.R. Landry, J. Constantinou, G. Rollwagen, A. Trasvina, and R. Kudela. 1996. A massive phytoplankton bloom induced by an ecosystemscale iron fertilization experiment in the equatorial Pacific Ocean. Nature, 383, 495-501.
Coale, K.H., X. Wang, S.J. Tanner, and K.S. Johnson. 2003. Phytoplankton growth and biological response to iron and zinc addition in the Ross Sea and Antarctic Circumpolar Current along $170^{\circ} \mathrm{W}$. Deep-Sea Res. II, 50, 635653.

Delmonte, B., J.R. Petit, and V. Maggi. 2002. Glacial to Holocene implications of the new 27000-year dust record from the EPICA Dome $\mathrm{C}$ (East Antarctica) ice core. Climate Dynam., 18, 647-660.

Dubischar, C.D., R.M. Lopes, and U.V. Bathmann. 2002. High summer abundances of small pelagic copepods at the Antarctic Polar Front - implications for ecosystem dynamics. Deep-Sea Res. II, 49, 3871-3887.

Henjes, H., P. Assmy, M. Montresor, and V. Smetacek. Response of the large protozooplankton and small metazooplankton to an iron-induced phytoplankton bloom during EIFEX. (in preparation)

Klaas, C., M. Schmidt, A. Terbrüggen, and D. Wolf-Gladrow. in preparation. Evolution of Chl a during EIFEX.

Krägefsky, S., U. Bathmann, S. Jansen, L. von Harbou, and Smetacek, V. Behaviour and accumulation of mesozooplankton during two iron fertilization experiments. (in preparation)

Landry, M.R., M.E. Ondrusek, S.J. Tanner, S.L. Brown, J. Constantinou, R.R. Bidigare, K.H. Coale, and S. Fitzwater. 2000. Biological response to iron fertilization in the eastern equatorial Pacific (IronEx II). I. Microplankton community abundances and biomass. Mar. Ecol. Prog. Ser., 201, 27-42.

Mahowald, N., K. Kohfeld, M. Hansson, Y. Balkanski, S.P. Harrison, I.C. Prentice, M. Schulz, and H. Rodhe. 1999. Dust sources and deposition during the last glacial maximum and current climate: A comparison of model results with paleodata from ice cores and marine sediments. J. Geophys. Res., 04(D13), 15895-15916.

Martin, J.H. and S.E. Fitzwater. 1988. Iron deficiency limits phytoplankton growth in the north-east Pacific subarctic. Nature, 331, 341-343.

Peeken, I., L. Hoffmann, and K. Lochte. Pigment based highlights from the Southern Ocean iron fertilization experiment EIFEX. (in preparation)

Riebesell, U., M. Altabet, P. Assmy, U. Bathmann, D. Bakker, A. Benthien, Y. Bozec, H. de Baar, F. Gervais, C. Harms, C. Hartmann, J. Henjes, S. Krägefsky, K.-U Richter, M. Rutgers van den Loeff, R. Sanders, U. chneider, V. Smetacek, V. Strass, A. Terbrüggen, I. Vöge, and A. Watson. Iron-fertilization induces carbon export in the Southern Ocean. (in preparation)

Sachs, O., E. Sauter, M. Schlüter, and I. Peeken. Benthic fluxes and pigments in deep-sea surface sediments of the EIFEX area. (in preparation)

Smetacek, V., U. Bathmann, and E. Helmke (Eds). 2005. The expedition ANTARKTIS XXI/3-4-5 of the research vessel Polarstern in 2004. Reports on Polar and Marine Research, 500. 302 p.

Smetacek, V. 2001. EisenEx: International Team Conducts 
Iron Experiment In Southern Ocean. U.S. JGOFS Newsletter, 40482.

Smetacek, V., P. Assmy, and J. Henjes. 2004. The role of grazing in structuring Southern Ocean pelagic ecosystems and biogeochemical cycles. Antarct. Sci., 16, 541558.

Strass, V., B. Cisewski, S. Gonzales, C. Klaas, H. Leach, I. Peeken, H. Rohr, and V. Smetacek. The physical setting of ocean-deep particle export during EIFEX. (in preparation)

Strass, V., B. Cisewski, S. Gonzales, H. Leach, K-D. Loquay, H. Prandke, H. Rohr, and M. Thomas. 2005. The physical setting of the European iron fertilization experiment EIFEX in the Southern Ocean. p. 15-45. In: The expedition ANTARKTIS XXI/3-4-5 of the research vessel olarstern in 2004. Reports on Polar and Marine
Research, 500. eds. by V. Smetacek, U. Bathmann, and E. Helmke.

Strass, V.H., U.V. Bathmann, M.M. Rutgers van den Loeff, and V. Smetacek. 2002. Mesoscale physics, biogeochemistry and ecology of the Antarctic Polar Front, Atlantic sector: An introduction to and summary of cruise ANT XIII/2 of R.V. Polarstern. Deep-Sea Res. II, 49, 37073711.

von Harbou, L., U. Bathmann, and I. Peeken. Pigments in salp guts - first results from HPLC analysis of gut contents from Salpa thompsoni collected during EIFEX cruise. (in preparation) 